\title{
OPTIMIZATION OF NOZZLE LAYOUT IN CONTINUOUS CASTING MACHINE
}

D.S. Safonov, Nosov Magnitogorsk State Technical University, Magnitogorsk, Russian Federation, dmitry.s.safonov@gmail.com, O.S. Logunova, Nosov Magnitogorsk State Technical University, Magnitogorsk, Russian Federation, logunova66@mail.ru, D.V. Chistiakov, KonsOM SKS, CJSC, Magnitogorsk, Russian Federation, dvc@konsom.ru

The article presents the results of the scientific research around development of mathamatical foundation for calculating optimal nozzle layout in secondary cooling zone of continuous casting machine and describes implementation of this foundation in specialized computer-aided design system. Optimization procedure is based on the 2-dimensional mathematical model of the thermal state of the slab, which accounts nozzle layout, and optimization criteria for the cross-cut thermal profile of the slab surface. Optimization problem solution consists of two basic blocks: solving thermal conductivity problem and iterative search of the nozzle positions that provide best solution from the point of proposed criteria. The results of running optimization procedure on input conditions based on existing casting machine showed that the obtained solution enables to provide smoother cross-surface thermal profile of the slab. Results of the work can be used for design of new continouous casting machines, modernization of the secondary cooling system of existing machines, and general numeric analisys of secondary cooling system operation for user-provided conditions.

Keywords: thermal state simulation; nozzle layout optimization; secondary cooling zone; continuous casting machine.

\section{Introduction}

Continuous casting machine $(\mathrm{CCM})$ is one of the components used in the metal making industries. The CCM design supposes the existence of basic components such as tundish, mold and secondary cooling zone.

In secondary cooling zone still-solidifying product, for example beam, slab, or billet is moving along the system of support rollers and is cooled by the water or airmist supplying from nozzles, placed between rollers. This work is dedicated mostly to slab casting, so later we will use slab as a term for casted product. From engeneering point of view the secondary cooling zone consistis of multiple sections connected to each other. During the secondary cooling process, the slab completely solidifies. Multiple conditions affect the solidification process: casting speed, cooling intensity, nozzle layout, nozzle types and parameters, steel grades, rollers cooling. And it is well known that solidification conditions have important effect on the internal and surface quality of the slab. Thus, a lot of work has been put into investigation of optimal solidification conditions [1-3]. However, the problem of selecting of optimal nozzle layout in SCZ has not received much attention yet. At the same time, current level of development of mathematical models of the thermal state of the slab allows to account nozzle layout, which makes possible to formalize the problem of determination of appropriate nozzle layout for CCM and automate this process. Presented work describes one possible way of such formalization. Particularly, the following problems were solved: 
1) construction of mathematical model of the slab in secondary cooling zone which accounts nozzle layout;

2) development of nozzle layout optimization algorithm, which includes formalization of the technological requirements for slab cooling in the form of complex criteria;

3) implementation of the mathematical model and optimization algorithm in specialized CAD system for calculation of optimal nozzle layout.

\section{A Mathematical Model of the Thermal State of the Slab}

Two-dimensional mathematical model of the thermal state of the slab in SCZ was used as a mathematical foundation for optimization process. Dynamic changes in boundary conditions were used to describe variations in the cooling conditions of the two-dimensional cross-section moving along the SCZ. The temperature field of the two-dimensional slab cross-section is described by the following classic equation [4]:

$$
\rho C_{\mathrm{eff}}(t)\left(\frac{\partial t}{\partial \tau}\right)=\frac{\partial}{\partial x}\left(\lambda_{\mathrm{eff}}(t) \frac{\partial \mathrm{t}}{\partial x}\right)+\frac{\partial}{\partial y}\left(\lambda_{\mathrm{eff}}(t) \frac{\partial t}{\partial y}\right)
$$

where $t$ is the temperature in ${ }^{\circ} \mathrm{C}$; $\rho$ is the density of steel in $\mathrm{kg} / \mathrm{m}^{3} ; C_{\text {eff }}(t)$ is the effective heat capacity of steel in $\mathrm{J} / \mathrm{kg} \cdot{ }^{\circ} \mathrm{C} ; \lambda_{e f f}(t)$ is the effective thermal conductivity of steel in $W / m \cdot{ }^{\circ} \mathrm{C}$.

The effective values are determined based on quasi-equilibrium model of twophase zone according to V.T. Borisov theory [5]. The thermal conductivity equation is supplemented by boundary conditions of the third kind:

$$
\begin{array}{cc}
\left.\lambda \frac{\partial t}{\partial x}\right|_{\mathrm{y}=0}=\alpha(x, 0, \tau)\left(t_{\mathrm{s}}(x, 0, \tau)-t_{\mathrm{e}}\right), & \left.\lambda \frac{\partial t}{\partial y}\right|_{\mathrm{x}=0}=\alpha(0, y, \tau)\left(t_{\mathrm{s}}(0, y, \tau)-t_{\mathrm{e}}\right), \\
-\left.\lambda \frac{\partial t}{\partial x}\right|_{\mathrm{y}=\mathrm{h}}=\alpha(x, \mathrm{~h}, \tau)\left(t_{\mathrm{s}}(x, \mathrm{~h}, \tau)-t_{\mathrm{e}}\right), & -\left.\lambda \frac{\partial t}{\partial y}\right|_{\mathrm{x}=\mathrm{w}}=\alpha(\mathrm{w}, y, \tau)\left(t_{\mathrm{s}}(\mathrm{w}, y, \tau)-t_{\mathrm{e}}\right),
\end{array}
$$

where $w, h$ are the thickness and width of the slab in $m$; $t_{s}$ is the slab surface temperature in ${ }^{\circ} \mathrm{C} ; t_{e}$ is the environment temperature in ${ }^{\circ} \mathrm{C} ; \alpha(x, y, \tau)$ is the heat transfer coefficient in $W / m^{2} \cdot K$.

Accounting of differences in cooling conditions at different areas of the slab surface is reflected in boundary conditions, dynamically changing in time and individually calculated for each point of the surface at one calculation step. During the modelling procedure crosssection surface moves between the areas with different types of cooling: nozzle cooling, roller contact and air cooling (Fig. 1).

The intensity of slab cooling varies between the types of areas and is not uniform within the selected area. The cooler from nozzles is nonuniformly distributed over the slab surface in the cooled areas (Fig. 2). This is caused by nozzle design specifics and leads to the differencies in the spraying density of the separate parts of the surface. In the roller contact areas we assume that the center of the slab surface is cooled more intensively then the corner parts because thinner strand at the center of the slab is pushed more tightly to roller by ferrostatic pressure and slab shrinkage in thickness on the corners may create a gap between roller an slab surfce.

Knowledge of the nozzle and roller layouts allows us to determine types of cooling areas for slab cross-section at any given calculation step. 


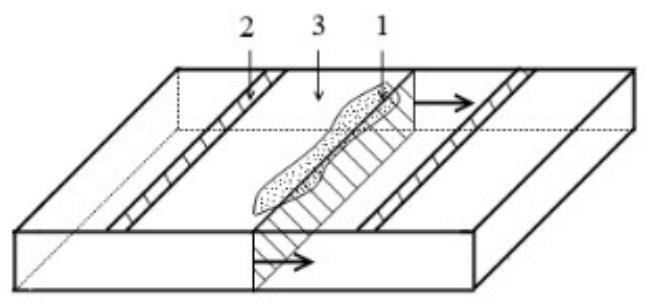

Fig 1. The areas with different types of slab surface cooling: 1 - nozzle cooling areas; 2 roller contact areas; 3 - air contact areas
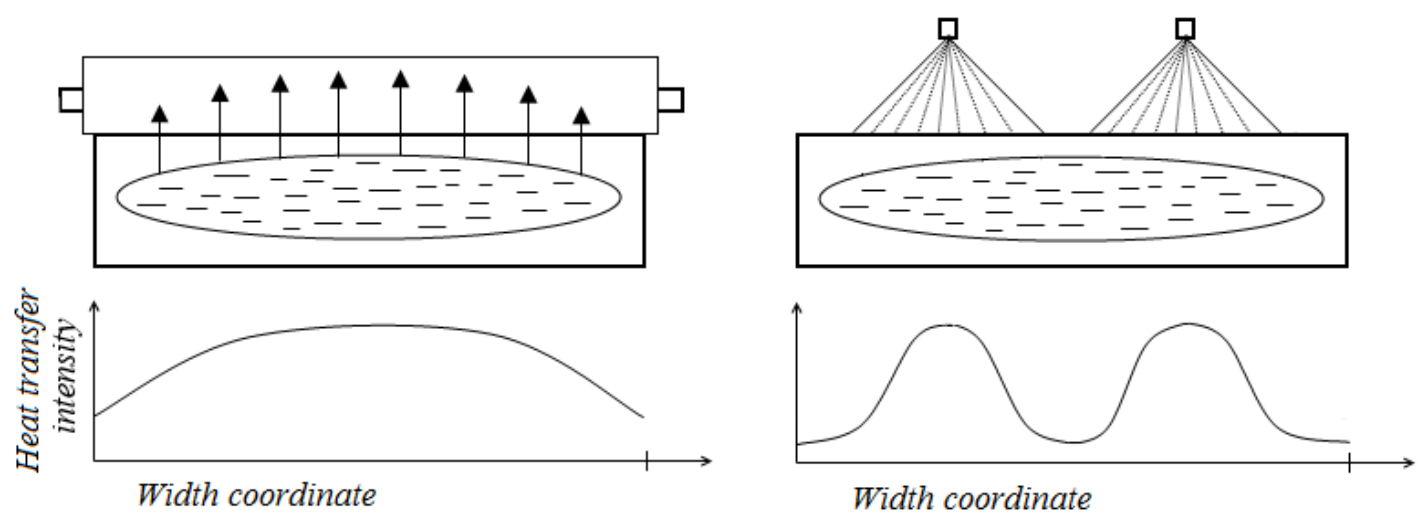

Fig 2. The differencies in the cooling intensity on the slab surface

The heat transfer coefficients for stated types of cooling areas are determined by the dependencies, presented in works of T. Nozaki, B. Thomas, R. Hardin [6-7], with some modifications:

$$
\begin{aligned}
\alpha_{\mathrm{n}}(x, z) & =k \cdot 1570 \cdot\left(\sum_{i=0}^{n} w_{x i}\left(x-x_{i}\right) \cdot p_{z i}\left(z-z_{i}\right)\right)^{0.55}\left(1-0.0075\left(t_{\mathrm{w}}\right)\right) ; \\
\alpha_{\mathrm{r}}(x) & =4 \frac{\left(\alpha_{\mathrm{rmin}}-\alpha_{\mathrm{rmax}}\right) x^{2}}{\mathrm{w}^{2}}+\alpha_{\mathrm{rmax}} ; \\
\alpha_{\mathrm{a}}(x, z) & =P \frac{\varepsilon \sigma_{0}\left(t_{\mathrm{s} \_\mathrm{abs}}(x, z)^{4}-t_{\mathrm{e} \_\mathrm{abs}}^{4}\right)}{t_{\mathrm{s} \_a b s}(x, z)-t_{\mathrm{e} \_\mathrm{abs}}}+\alpha_{\mathrm{conv}}+Q \cdot G(z),
\end{aligned}
$$

where $\alpha_{\mathrm{n}}, \alpha_{\mathrm{r}}, \alpha_{\mathrm{a}}$ are heat transfer coefficients in the nozzle cooling areas, roller contact and air contact in $W / m^{2} \cdot K ; w_{x i}$ is one-dimensional local spraying density of nozzle $i$ at the distance $x$ from the nozzle jet on the axis $x$ in $L / \cdot s ; p_{z i}$ is relative spraying density of nozzle $i$ at the distance $z$ from the nozzle jet on the axis $z$ in $1 / m ; x_{i}, z_{i}$ are coordinates of the jet projection of the $i$-th nozzle on the slab surface; $i \in(1 . . n)$ are indexes of nozzles in spraying areas of which surface point with coordinates $(x, z)$ depends; $t_{w}$ is the temperature of cooling water, $t_{s} a b s(x, z), t_{e}$ abs are absolute surface and environment temperatures in $\mathrm{K} ; \varepsilon$ is given emissivity coefficient of the body; $\sigma_{0}$ is the Stefan - Boltzmann constant; 
$G(x, z)$ is the average cooling flow rate on the slab surface in secondary cooling section to which the point $(x, z)$ belongs, $L /{ }^{2} \cdot s ; k, \alpha_{\text {rmin }}, \alpha_{\text {rmax }}, \alpha_{\text {conv }}, P, Q$ are empirical constants.

System of equations (1) - (2) was solved by alternating direction implicit method using Peaceman - Rachford scheme.

\section{Optimization of the Nozzle Layout}

In order to develop a method to optimize the nozzle arrangement layout in the secondary cooling zone the concept of crosscut thermal profile of the slab surface and optimization criteria were introduced. We consider the crosscut thermal profile in discrete form as a vector of temperatures $t_{i}$ at the points $x_{i}, i=1, \ldots, n$, where $n$ is the number of calculating points on the imaginary line on a slab surface which is perpendicular to casting direction.

There are many known techonological requirements to the thermal profile of the slab $[1-2,8,10]$. Great work has already been done in the field of controling of cooling rates to provide optimal cooling profile in casting direction [9-10]. But in this research authors are trying to supplement existing knowledge by looking at the cross-cut thermal profile of the slab surface.

The most basic technological requirements to cross-cut thermal profile are minimization of the value of absolute temperature gradient per unit of cross-cut line length and thermal profile symmetry relative to the center of the surface. This requirements were formalized in form of optimization critera:

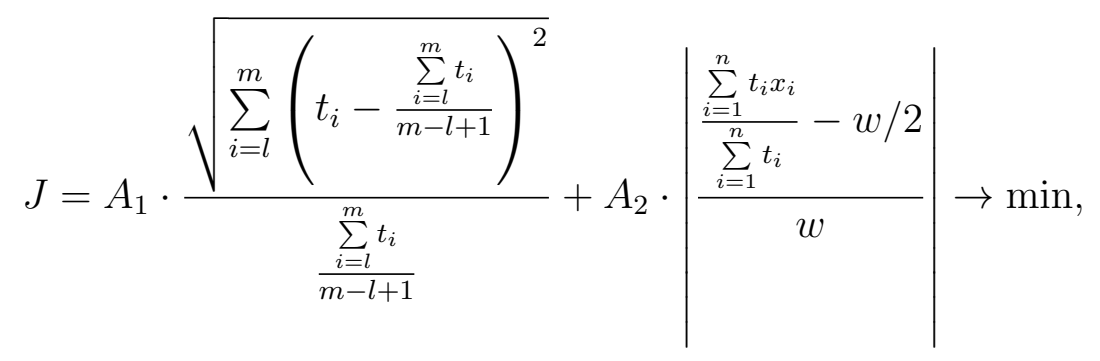

where A1, A2 are the weight coefficients determined by an expert. The idea behind critera is that it is a linear combination of two constituents, the first one evaluates the temperature variation relative to average temperature value at the profile points (points, which are adjacent to the corners closer than $5 \%$ of suface width, are excluded from consideration, hence the indices $l$ and $m$ ) and characterizes the thermal profile uniformity. The graphical representation of the first constituent is shown in Fig. 3.

The second constituent of the criteria characterizes the thermal profile symmetry relative to the surface center by accounting temperature of discrete points of crosscut thermal profile as their mass and calculating the distance between "thermal" mass center and surface center (Fig. 4).

Developed criteria and mathematical model allow us to state the optimization problem in order to find nozzle positions in SCZ. Suppose that the initial nozzle layout is given and contain $K$ rows of nozzles, in each $k$-th row there are $n_{k}$ nozzles and their positions are given as coordinate vector $\left.X_{k}\left(x_{k 1}, x_{k 2}, \ldots, x_{k n_{k}}\right)\right)$. Denote the exit point out of the $k$-th row spraying arya by $z_{k}$, the temperature vector of the points on cross-cut line at the position $z_{k}$ by $T_{z_{k}}\left(t_{1 z_{k}}, t_{2 z_{k}}, \ldots, t_{m z_{k}}\right)$, the discretization frequency over the slab width by $m$ and the slab width by $w$. 

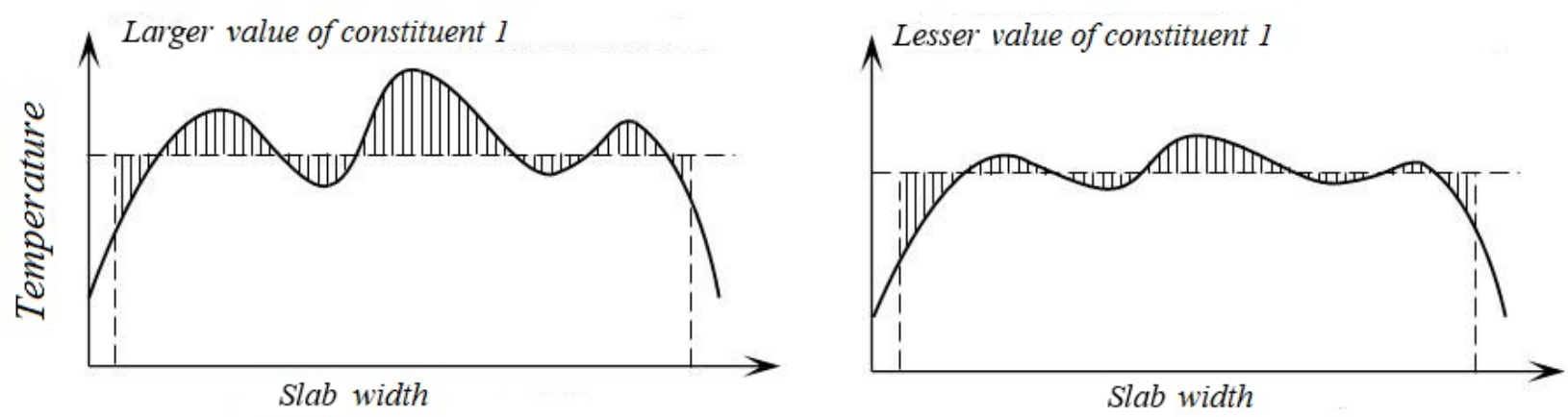

Fig 3. The graphical representation of the first criteria constituent: left image - the temperature distribution over the slab width providing nonuniform cooling over the width; right image - the temperature distribution over the slab width under approximately uniform surface cooling over the width

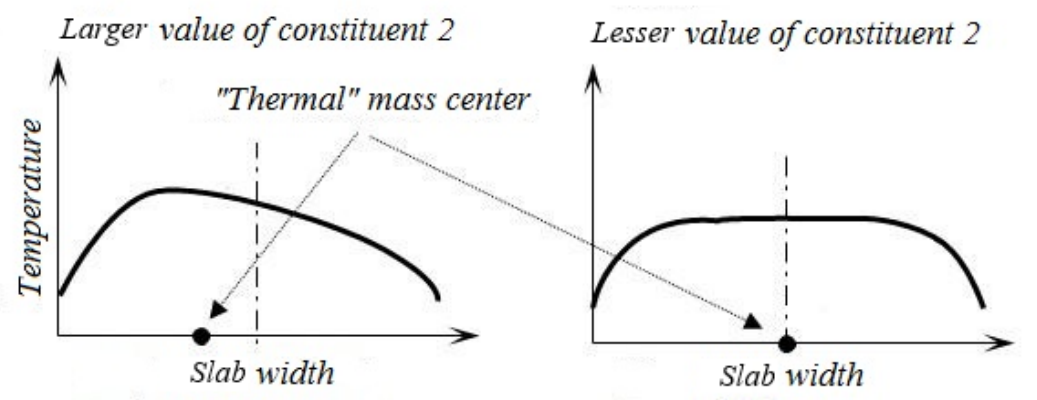

Fig 4. The graphic representation of the second criteria constituent

Optimization problem is stated as follows: we need to find a set of vectors $X=$ $\left\{X_{1} . . X_{k}\right\}$, each element of which is a nozzle coordinate vector in one space between rollers (or coordinate vector of one nozzle row) and nozzle coordinates are parameters of the slab temperature evaluation procedure, for which the optimization criteria reaches its minimum value:

$$
J\left(T_{z_{k}}\left(X_{k}\right)\right) \rightarrow \min , 1 \leq k \leq K
$$

under restrictions

$$
\begin{aligned}
& x_{k_{i-1}}<x_{k_{i}}<x_{k_{i+1}}, 2 \leq i \leq n_{k}-1 \\
& 0,05 w \leq x_{k} \leq 0,95 w, 1 \leq i \leq n_{k} \\
& x_{k_{i}}=0,05 p, p \in \mathbb{N} .
\end{aligned}
$$

Actual optimization procedure could be described as follows. Given is the initial nozzle layout $X_{\text {init }}=\left\{X_{1}, \ldots, X_{k}\right\}$. The optimization procedure is executed sequentially for each row inside thermal state simulation procedure. The slab cross-section thermal state is considered to be known at the entry point to the particular nozzle row spraying area as a result of simulation. The simulation state is recorded in this position. The simulation of the slab cross-section thermal state is continued to the exit point.

The objective function value $J\left(T_{z_{k}}\left(X_{k}\right)\right)$ is computed at the exit point. This value is obtained using initial nozzle positions. If we rollback the simulation process to the state 
at the enter position and make adjustments to the nozzle positions, and then repeat the computing to the exit position we get the objective function value $J\left(T_{z_{k}}\left(X_{k}^{\prime}\right)\right)$ for adjusted nozzle positions.

Thus, simulation of the thermal state of the slab cross-section from the enter position to the exit position is a procedure for calculating of the value of objective function $J\left(T_{z_{k}}\left(X_{k}\right)\right)$ for the arbitrary vector $X_{k}$. That allows us to use random search algorithm for finding of optimal $X_{k}$. We obtain the optimal nozzle arrangement layout for the whole SCZ by consecutively optimizing the nozzle arrangement in each row along casting direction.

\section{Implementation of the Optimization Algorithm in Computer-Aided Design System}

Developed mathematical model of the thermal state of the slab and algorithm for nozzle layout optimization were implemented in specialized computer-aided design system for calculation optimal nozzle layout and simulation of thermal state of the slab using different nozzle layouts and technological conditions (Fig. 5).
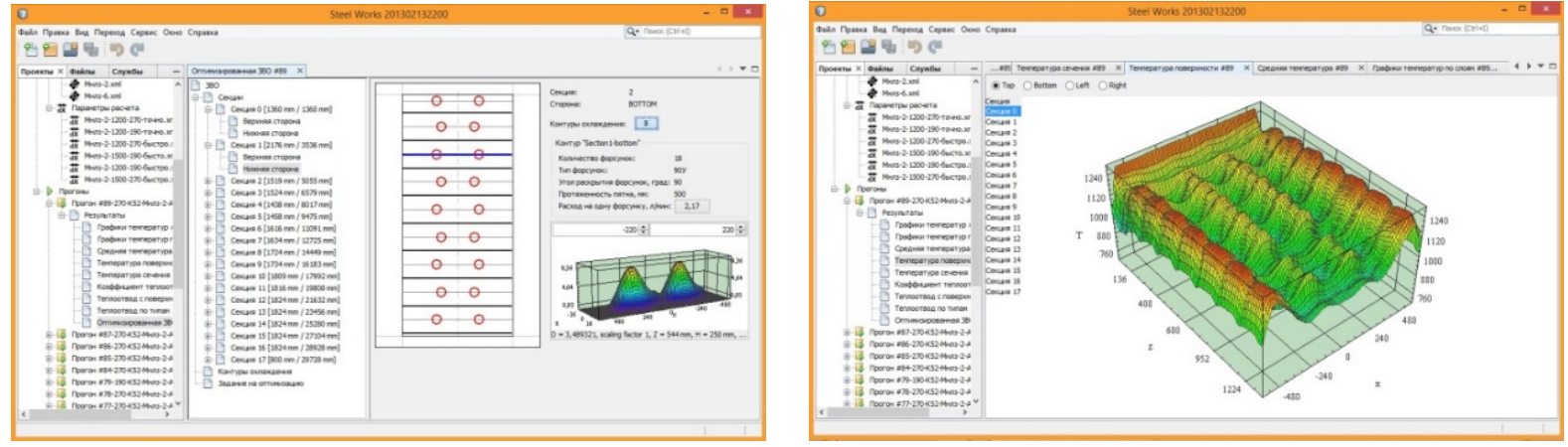

Fig 5. Screen forms of the computer-aided design system for calculation of optimal nozzle layout in secondary cooling zone: a - view of the nozzle layout in selected secondary cooling section; $b$ - surface plot for temperature on the top side of the slab in selected secondary cooling section

This system was used to calculate optimal nozzle layout for CCM in Ural Steel OJSC (Open Joint-Stock Company). Nozzle layout optimization was performed for the following input conditions: slab cross-cut size of $1200 \times 270 \mathrm{~mm}$, steel grade from the K-52 group, casting speed of $0,9 \mathrm{~m} / \mathrm{min}$. Current nozzle layout was used as initial layout. Fig. 6 shows the results of a comparison of the thermal fields on the slab surface using initial and optimized nozzle layouts, and Fig. 7 shows the the difference between current and optimized nozzle layouts in example secondary cooling sections.

Based on the series of the optimization procedure runs it was found that the variation of casting speed by $\pm 0,1 \mathrm{~m} / \mathrm{min}$, cooling rates by $\pm 10 \%$ didn't cause visible changes to optimal layout. Changing slab width, howerer, caused changes in optimal layout.

\section{Conclusion}

A mathematical model of the thermal state of the slab, which takes into account nozzle layout in secondary cooling zone of continuous casting machine, was constructed. 


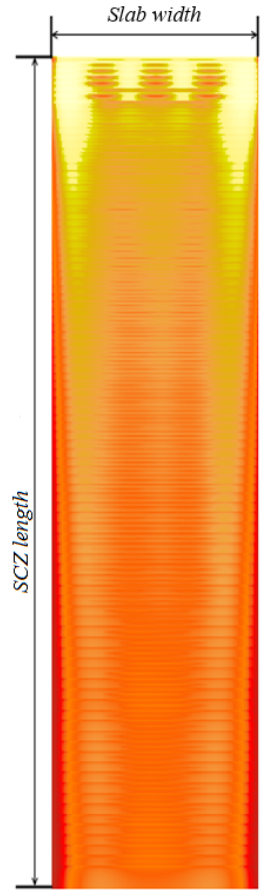

a

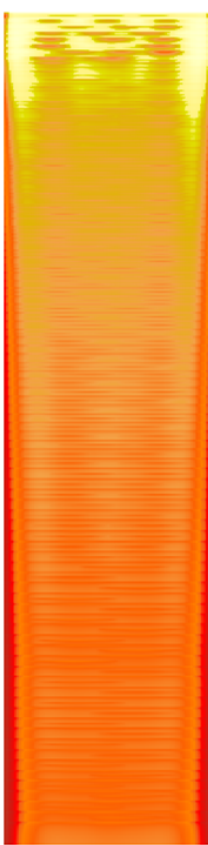

$\mathrm{b}$
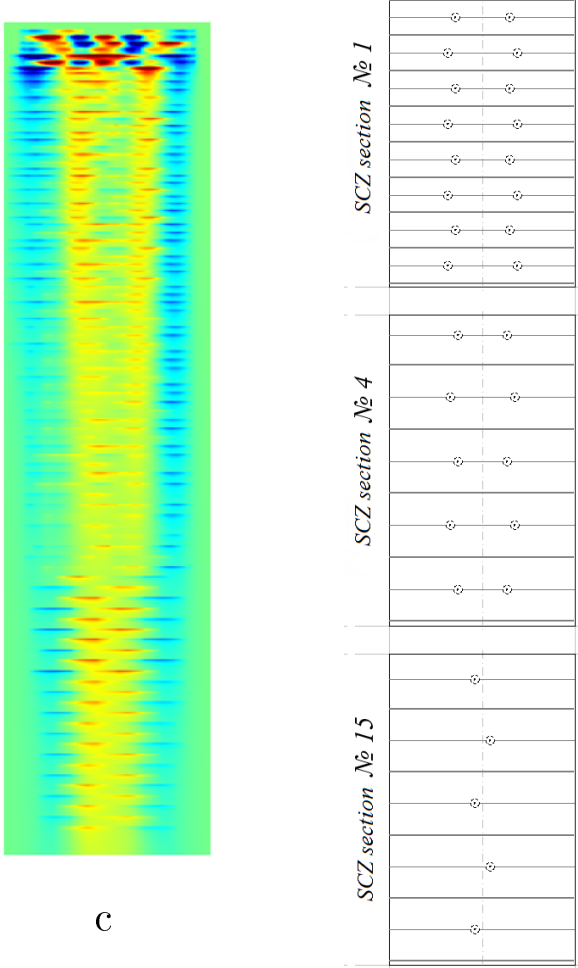

a
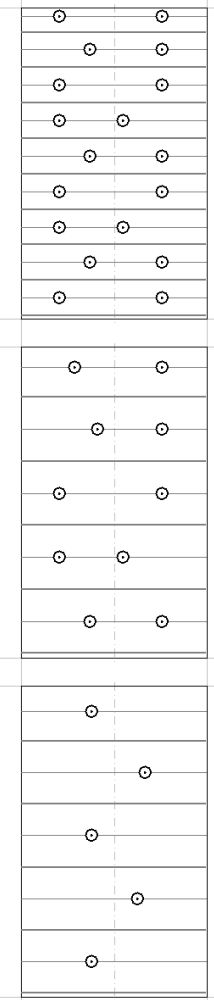

$\mathrm{b}$
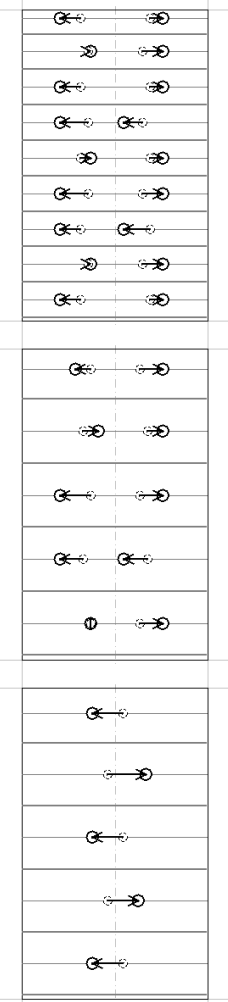

C fields on the slab surface: a - under conditions of the initial layout; $b$ - under conditions of optimal nozzle arrangement layout; $c$ - temperature diff when switching to the optimal layout
Fig 7. Changes in the solution of the optimization problem: a - the initial layout; b - optimal layout; c - corrections in layout

In addition to that, basic technological requirements to the thermal profile of the slab surface cross-section, in particular, symmetry and uniformity, were formalized in form of complex criteria. That allowed to develop optimization algorithm for calculation of optimal nozzle layout in secondary cooling zone, aiming to provide more rational colling of the slab surface and reduce risks of crack development. This algorithm was implemented in specialized computer-aided design system for calculating optimal nozzle layout and analyzing thermal state of the slab in secondary cooling zone.

\section{References}

1. Bulanov L.V., Korzunin L.G., Parfenov E.P., et. al. Mashiny nepreryvnogo lit'ya zagotovok. Teoriya i raschet [Continuous Casting Machine: Theory and Design]. Yekaterinburg, 2004. 320 p. (in Russian)

2. Evteev D.P., Kolybalov I.N. Nepreryvnoye lit'yo stali [Continuous Casting of Steel]. Moscow, 1984. 200 p. (in Russian)

3. Hardin, R., Liu, K., Beckermann, C., Kapoor, A. A Transient Simulation and dynamic Spray Cooling Control Model for Continuous Steel Casting. Metallurgical and materials transactions B, 2003, vol. 34 , no. 3, pp. 297-306. 
4. Samoilovich, Y.A., Kruleveckiy S.L., Goryainov V.A., Kabakov Z.K. Teplovye processy pri nepreryvnom lit'ye stali [Heat Processes in Continuous Casting of Steel]. Moscow, 1982. 152 p. (in Russian)

5. Borisov V.T. Teoriya dvuhfaznoi zony metallicheskogo slitka [Theory of the Two-Phase Zone of Metal Ignot]. Moscow, 1987. 222 p. (in Russian)

6. Meng, Y., Thomas, B. Heat transfer and solidification model of continuous slab casting: CON1D. Metallurgical and Materials Transactions, 2003. no. 5, pp. 685-705.

7. Meng, Y., Thomas, B. Simulation Using Realistic Spray Cooling for the Continuous Casting of Multicomponent Steel. Journal of Materials Science and Technology, 2002, vol. 18, pp. $123-128$.

8. Vdovin K.N., Tochilkin V.V., Yachikov I.M. Nepreryvnaya razlivka stali: monografiya [Continuous Casting of Steel: Monography]. Magnitogorsk, 2012. 590 p. (in Russian)

9. Stolyarov A.M., Kazakov A.S. Vtorichnoye ohlazhdeniye nepreryvnolityh slyabov na krivolineynoy MNLZ s vertikal'nym uchastkom [Secondary Cooling of the Continuously Casted Slabs in Curvilinear CCM with Vertical Part]. Magnitogorsk, 2011. 116 p. (in Russian)

10. Logunova, O.S., Matsko, I.I, Posohov, I.A., Luk'ynov, S.I. Automatic System for Intelligent Support of Continuous Cast Billet Production Control Process. The International Journal of Advanced Manufacturing Technology, 2014, vol. 74, no. 9-12, pp. 1407-1418.

Received November 10, 2015

УДК 621.745.3:66.042.3

DOI: $10.14529 / \mathrm{mmp} 160109$

\title{
ОПТИМИЗАЦИЯ СХЕМЫ РАСПОЛОЖЕНИЯ ФОРСУНОК В МАШИНЕ НЕПРЕРЫВНОГО ЛИТЬЯ ЗАГОТОВОК
}

\author{
Д.С. Сафонов, О.С. Логунова, Д.В. Чистяков
}

В статье представлены результаты исследования, посвященного разработке математических основ для поиска оптимальной схемы расположения форсунок в зоне вторичного охлаждения машины непрерывного литья заготовок, а также описана реализация данных основ в рамках специализированной системы автоматизации проектирования. Процедура оптимизации основана на двумерной математической модели теплового состояния заготовки, учитывающей схему расположения форсунок, а также критерии оптимальности поперечного теплового профиля поверхности заготовки. Решение задачи оптимизации достигается путем итеративного моделирования теплового состояния заготовки и поиска таких позиций форсунок, при который результаты моделирования оказываются наилучшими с точки зрения предложенного критерия. Выполнение процедуры оптимизации на входных условиях, основанных на параметрах существующей машины непрерывного литья заготовок, показало, что оптимальная схема расположения форсунок позволяет обеспечить более гладкий поперечный тепловой профиль поверхности заготовки. Результаты исследования могут быть использованы в процессе проектирования новых машин непрерывного литья заготовок, модернизации существующих, а также для численных исследований работы системы вторичного охлаждения при различных параметрах.

Ключевые слова: моделирование теплового состояния заготовки; оптимизация схемы расположения форсунок; зона вторичного охлаждения; машина непрерывного литья заготовок.

Вестник ЮУрГУ. Серия «Математическое моделирование

и программирование» (Вестник ЮУрГУ ММП). 2016. Т. 9, № 1. С. 114-122 


\section{Литература}

1. Буланов, Л.В. Машины непрерывного литья заготовок. Теория и расчет / Л.В. Буланов, Л.Г. Корзунин, Е.П. Парфенов [и др.]. - Екатеринбург: Уральский центр PR и рекламы «Марат», 2004. - 320 c.

2. Евтеев, Д.П. Непрерывное литье стали / Д.П. Евтеев, И.Н. Колыбалов. - М: Металлургия, 1984. - 200 с.

3. A Transient Simulation and Dynamic Spray Cooling Control Model for Continuous Steel Casting / R. Hardin, K. Liu, C. Beckermann, A. Kapoor // Metallurgical and Materials Transactions B. - 2003. -V. 34, № 3. - P. 297-306.

4. Самойлович, Ю.А. Тепловые процессы при непрерывном литье стали / Ю.А. Самойлович, С.Л. Крулевецкий, В.А. Горяинов, З.К. Кабаков. - М.: Металлургия, 1982. - 152 с.

5. Борисов, В.Т. Теория двухфазной зоны металлического слитка / В.Т. Борисов. - М.: Металлургия, 1987. - 222 с.

6. Meng, Y. Heat Transfer and Solidification Model of Continuous Slab Casting: CON1D / Y. Meng, B. Thomas // Metallurgical and Materials Transactions. - 2003. - № 5. - P. 685-705.

7. Meng, Y. Simulation Using Realistic Spray Cooling for the Continuous Casting of Multicomponent Steel / Y. Meng, B. Thomas // Journal of Materials Science and Technology. - 2002. - V. 18. - P. 123-128.

8. Вдовин, К.Н. Непрерывная разливка стали: монография / К.Н. Вдовин, В.В. Точилкин, И.М. Ячиков. - Магнитогорск: Изд-во Магнитогорск. гос. техн. ун-та им. Г.И. Носова, 2012. $-590 \mathrm{c}$.

9. Столяров, А.М. Вторичное охлаждение непрерывнолитых слябов на криволинейной МНЛЗ с вертикальным участком: монография / А.М. Столяров, А.С. Казаков. - Магнитогорск: Изд-во Магнитогорск. гос. техн. ун-та им. Г.И. Носова, 2011. - 116 с.

10. Automatic System for Intelligent Support of Continuous Cast Billet Production Control Process / O.S. Logunova, I.I. Matsko, I.A. Posohov, S.I. Luk'ynov // The International Journal of Advanced Manufacturing Technology. - 2014. - V. 74, № 9-12. - P. 1407-1418.

Дмитрий Сергеевич Сафонов, кафедра вычислительной техники и программирования, Магнитогорский государственный технический университет им. Г.И. Носова (г. Магнитогорск, Российская Федерация), dmitry.s.safonov@gmail.com.

Оксана Сергеевна Логунова, доктор технических наук, доцент, кафедра вычислительной техники и программирования, Магнитогорский государственный технический университет им. Г.И. Носова (г. Магнитогорск, Российская Федерация), logunova66@mail.ru.

Дмитрий Владимирович Чистяков, кандидат социологических наук, ЗАО «КонcOM CKC»,dvc@konsom.ru.

Поступила в редакиию 10 ноября 2015 г. 